\title{
Thyroid peroxidase activity, hepatic glucose-6-phosphate dehydrogenase activity and corticosterone level in plasma and tissues of rats fed different dietary fats
}

\section{Rosolowska-Huszcz ${ }^{1,4}$, J. Gromadzka-Ostrowska ${ }^{1}$, J. Wilczak ${ }^{2}$, K. Romanowicz ${ }^{3}$, M. Borysiak ${ }^{1}$, M. Dębska' ${ }^{1}$ and B. Mazurek ${ }^{1}$}

\author{
Warsaw Agricultural University \\ Nowoursynowska 166, 02-787, Warsaw, Poland \\ 'Department of Dietetics, \\ Faculty of Human Nutrition and Home Economics \\ ${ }^{2}$ Department of Animal Physiology. Faculty of Veterinary Sciences \\ ${ }^{3}$ The Kielanowski Institute of Animal Physiology and Nutrition. \\ Polish Academy of Sciences \\ 05-llo Jablonna, Poland
}

(Received 6 December 1999; revised version 6 June 2000; accepted 22 January 2001)

\section{ABSTRACT}

Thyroid and adrenal gland activity were evaluated together with liver lipogenic activity in rats fed diets containing different fats. After one- week of a fat- free regimen, male Wistar rats weighing $100-120 \mathrm{~g}$ (at the beginning of the experiment) were divided into four groups fed diets with different fats: L - lard, S - sunflower oil, P - palm oil, R - rape seed oil. The activity of thyroid peroxidase (TPO), the key enzyme in thyroid hormone biosynthesis, corticosterone (Cs) concentration in plas$\mathrm{ma}$, the adrenal glands, aorta, and heart, plasma total cholesterol concentration and glucose-6-phosphate dehydrogenase (G-6-PD) activity in the liver, as an index of lipogenic activity, were determined after fat-free feeding and after one and three weeks of fat-supplying diets. TPO activity increased after one week on fat-containing dicts fed to groups S and P; after three weeks it was higher than after the fat-free period in groups $\mathrm{P}, \mathrm{S}$ and $\mathrm{L}$ and directly related to palmitic acid intake and plasma total cholesterol concentration. Various patterns of changes in Cs concentration in plasma and tissues were observed suggesting an influence of dietary fat composition on hormonc distribution. After three weeks of feeding fat, Cs concentration in plasma was lower than after the fat-free

\footnotetext{
${ }^{4}$ Corresponding author
} 
regimen and did not differ among dietary groups, while in tissues it was dependent on the type of dictary fat. Tissue Cs was higher in the adrenals in groups $P$ and $R$, in the aorta in group $R$, and in the heart in groups $\mathrm{L}$ and $\mathrm{S}$. After three weeks of feeding fat the Cs concentration in the aorta of groups $\mathrm{S}$ and $\mathrm{L}$, and in the adrenals in group $\mathrm{S}$ was lower than after the fat- free regimen, whereas in the heart it was higher in all groups. The decrease in hepatic G-6-PD activity after introducing diets with fats depended on the kind of dietary fat; it decreased to lower levels in groups $S$ and $R$ than in groups $L$ and $\mathrm{P}$.

The results obtained indicate that dietary fat composition can affect thyroid activity, hepatic lipogenesis and corticosterone secretion and/or distribution in different manners. This suggests that, among others, metabolic effects of dietary fat can result from changes in relations between thyroid and adrenal gland activities.

KEY WORDS: adrenal gland, corticosterone, dietary fat, glucose-6-phosphate dehydrogenase. thyroid peroxidase

\section{INTRODUCTION}

The role of the thyroid and adrenal glands in regulating energy balance implics a dependence of their activity on the amount and composition of consumed food. Dietary fat composition has been shown to affect triiodothyronine $\left(\mathrm{T}_{3}\right.$ ) (Takeda et al., 1994) and thyroxine $\left(\mathrm{T}_{4}\right)$ (Smith et al., 1993) plasma concentrations. Experiments performed in vitro and with infusions of free fatty acids (FFA) have demonstrated that FFA compete with thyroid hormone in binding to plasma transport proteins and nuclear receptors and decrease circulating TSH secretion depending on their chain length and saturation (van der Klis, 1991; Lim et al., 1995). The effect of different fatty acids on glucocorticoid secretion is not quite clear. In experiments in vitro, steroidogenesis in cultured rat adrenocortical cells was found to be stimulated by pathological concentrations of oleic and linoleic acids and unaffected by stcaric and caprylic acids (Sarel and Widmaier, 1995). In in vivo studies, however, corticosterone plasma concentration was demonstrated to be independent of the type of dietary fat (Kamara et al., 1998).

Due to the stimulating effect of the thyroid on mitochondrial biogenesis and respiration rate (Freake et al., 1989), Na, K-ATP-ase activity (Lin, 1979), lipolysis (Freake et al., 1989) and synthesis of termogenin (Bianco et al., 1988) as well as cholesterol $7 \alpha$-hydroxylase (Ness and Lopez, 1995) and low-density lipoprotein receptors (Abrams and Grundy, 1981), decreases in thyroid activity evoked by dietary fat can lead to the development of obesity and circulatory diseases. Dietary fat may provoke the same effects by increasing adrenal cortex activity, taking into consideration its atherogenic and lipogenic influences (Bray et al., 1990; Dallman et al., 1993; Garrel, 1997). Knowledge of the effects exerted by different dietary fats on thyroid activity and glucocorticoid secretion seems to be important in respect to prevention of circulatory diseases and obesity. 
The present study was designed to assess the effects of feeding commercially available dietary fats on thyroid and adrenal cortex activity together with plasma cholesterol concentration and intensity of fatty acid synthesis in the liver. Endocrine activity was assessed by determining thyroid peroxidase (TPO), a key, membrane-bound enzyme in thyroid hormone biosynthesis that catalyzes oxidation of iodide, the iodination of thyrosyl residues in thyroglobulin and their coupling (Nunez, 1980), as well as the concentration of corticosterone (Cs) in blood plasma, adrenal glands, the aorta and heart. The intensity of lipogenesis in the liver was measured by glucose-6-phosphate dehydrogenase (G-6-PD) activity, a key regulatory enzyme of the pentose phosphate pathway yielding NADPH for fatty acid biosynthesis.

\section{MATERIAL AND METHODS}

\section{Experimental design}

Male Wistar rats ( $\mathrm{n}=71$ ) weighing $100-120 \mathrm{~g}$ at the beginning of the experiment were housed in standard environmental conditions. The rats were allowed free access to water and diets. During the weck of the standardization, they received standard rodent feed, then they were given a fat-free diet during the following week. Afterwards, the rats were divided into four groups fed diets with different fats: lard (L), sunflower oil (S), palm oil (P) and rape seed oil (R) during the subsequent three wecks. Dict compositions are given in Table 1. Fatty acid intakes were calculated from data given for palm oil by Ariffin et al. (1994) and for the other fats by Łoś-Kuczera and Piekarska (1988). Body mass and food intakes were measured every three days.

Some of the rats were sacrificed after one week of the fat-free diet $(n=8)$ and after one week $(n=6)$ and three weeks $(n=10$ for $S, L$ and $P ; n=9$ for $R)$ of consuming diets containing fat. They were anaesthetized with diethyl ether and blood was taken by cardiac puncture. Then the thyroid and adrenal glands, heart and aorta were weighed and immediately frozen in liquid nitrogen and stored at $-80^{\circ} \mathrm{C}$ until examination.

\section{Analyses}

Chemicals were purchased from Sigma Chemical Co. (St. Louis, MO).

Thyroid peroxidase activity was determined in the thyroid microsomal fraction prepared as described previously (Rosolowska-Huszcz, 1998). Briefly: thyroids were thawed, washed in physiological saline and homogenized in $1.1 \%$ $\mathrm{KCl}$ in a motor-driven Potter Elvehjem homogenizer for $1 \mathrm{~min}$ and centrifuged 
TABLE 1

Composition of diets, $\mathrm{g} / \mathrm{kg}$

\begin{tabular}{lcc}
\hline Componcnt & Fat - frec & Fat - contained \\
\hline Casein & 220 & 220 \\
Maize starch & 690 & 590 \\
Potato starch & 45.8 & 45.8 \\
Fat & - & 100 \\
Mineral mixture' & 30 & 30 \\
Mineral mixturc & 10 & 10 \\
L-methionine $^{2}$ & 2.2 & 2.2 \\
Choline chloride & 2 & 2 \\
\hline
\end{tabular}

1 mineral mixture contained in $1 \mathrm{~kg}$ " $735 \mathrm{~g} \mathrm{CaHPO} 4 \times 2 \mathrm{H} 2 \mathrm{O}, 81 \mathrm{~g}$ K2HPO4, $68 \mathrm{~g} \mathrm{~K} 2 \mathrm{SO} 4.30 .6 \mathrm{~g}$ $\mathrm{NaCl}, 21 \mathrm{~g} \mathrm{CaCO}, 21.4 \mathrm{~g} \mathrm{Na} 2 \mathrm{HPO} 4 \times 2 \mathrm{H} 2 \mathrm{O}, 25 \mathrm{~g} \mathrm{MGO}$ and $18 \mathrm{~g}$ microelement mixture (in $100 \mathrm{~g}: 31 \mathrm{~g} \mathrm{C} 3 \mathrm{H} 4(\mathrm{OH})(\mathrm{COO}) 2 \mathrm{Fe}, 4.5 \mathrm{~g} \mathrm{ZnCO}, 23.4 \mathrm{~g} \mathrm{MnCO} 3,1.85 \mathrm{~g} \mathrm{CuCO} 3,39.2 \mathrm{~g}$ $\mathrm{C} 3 \mathrm{H} 4 \mathrm{OH}(\mathrm{COOH}) 3,0.04 \mathrm{~g} \mathrm{KJ}$

2 vitamin mixture contained in $1 \mathrm{~kg}: 2 \mathrm{mln}$ i.u. vit. A, 200000 i.u. vit. D3, $10000 \mathrm{i}$.u. vit. E, $0.5 \mathrm{~g}$ vit. $\mathrm{K}, 4 \mathrm{~g}$ niacin, $4 \mathrm{~g}$ calcium pantothenate, $0.5 \mathrm{~g}$ vit. $\mathrm{B} 1,0.8 \mathrm{~g}$ vit. $\mathrm{B} 2,0.5 \mathrm{~g}$ vit. $\mathrm{B} 6,0.2 \mathrm{~g}$ folic acid, 0.04 biotin $0,0.003 \mathrm{~g}$ vit. B12, $10 \mathrm{~g}$ para-aminobenzoic acid, $10 \mathrm{~g}$ inositol, $769.5 \mathrm{~g}$ starch

( $15 \mathrm{~min} \times 1500 \mathrm{~g}$ ). The pellet was discarded and the supernatant was centrifuged $(1 \mathrm{~h} \times 105000 \mathrm{~g})$. The pellet was suspended in $200 \mu \mathrm{l} 20 \mathrm{mM}$ phosphate buffer pH 7.4 with $10 \mu 10.1 \%$ Triton $\times 100$. TPO activity was measured by iodide oxidation assay (14). The reaction mixture contained $50 \mathrm{mM}$ phosphate buffer $\mathrm{pH} 7.4,0.135 \mathrm{mM} \mathrm{H}_{2} \mathrm{O}_{2}, 13 \mathrm{mM} \mathrm{KI}$ and about $50 \mu \mathrm{g}$ of cytosolic protein. Iodide oxidation was followed at $350 \mathrm{~nm}$ for $2 \mathrm{~min}$ at $5-\mathrm{s}$ intervals at room temperature. The amount of enzyme that gave a change of 0.001 absorbance per second was defined as 1 unit. Protein concentration was determined by the method of Lowry et al. (1951).

Glucose-6-phosphate dehydrogenase activity was estimated in the liver cytosolic fraction with a slight modification of the procedure described by Lee (1982). The assay was carried out by measuring the formation of NADPH at $25^{\circ} \mathrm{C}$ for $5 \mathrm{~min}$ at 15 -s intervals at $340 \mathrm{~nm}$. The reaction mixture consisted of $50 \mathrm{mM}$ TRIS buffer, pH 7.6 containing $6 \mu \mathrm{M}$ EDTA, $4.2 \mathrm{mM}$ glucose-6-phosphate, $1 \mathrm{mM} \mathrm{NADP}$ and about $100 \mu \mathrm{g}$ of cytosolic protein. G-6-PD activity was expressed as optical density change per min per mg protein. The protein concentration was measured by the method of Lowry et al. (1951).

Plasma total cholesterol concentration was cstimated by the method of Watson (Mangold and Bezzegh, 1974).

Adrenals, heart and aorta for estimation of Cs concentration were thawed, homogenized by powdering in liquid nitrogen and suspended in $5 \mathrm{mM}$ phosphate buffer $\mathrm{pH} 7.4$ with $0.1 \%$ gelatin. Homogenates were centrifuged for $60 \mathrm{~min}$ at 
$105000 \mathrm{~g}$. One milliliter of soluble fractions of all tissues was double extracted with diethyl ether. Percent recoveries after extraction for adrenals, heart and aorta were $67,58-83$ and $56-78 \%$, respectively. Corticosterone was measured by radioimmunoassay in tissue cytosol fraction extracts or directly without extraction in plasma according to the technique described by Stupnicki (1985). Plasma Cs binding globulin (transcortin) was inactivated by heating of samples at $80^{\circ} \mathrm{C}$ for 20 min. Highly specific anti-Cs antibodies (cross reactions with cortisol, dexamethasone, cortisone and hydroxyprogesterone were $12,8,3$ and $2 \%$, respectively) were kindly obtained from The Kielanowski Institute of Animal Physiology and Nutrition, Polish Academy of Sciences, Jabłonna. The assay sensitivity and the intraand interassay coefficient of variation were $10.0 \mathrm{pg} / \mathrm{ml}, 3.2$ and $4.5 \%$ for tissue cytosol extracts and $12.5 \mathrm{pg} / \mathrm{ml}, 5.4$ and $7.6 \%$ for blood plasma.

Corticosterone concentration was expressed as $\mathrm{pg} / \mathrm{mg}$ of cytosol protein. Total cytosol protein concentration was determined by the method of Lowry et al. (1951) using crystalline bovine serum albumin as a standard.

\section{Statistical analysis}

The data concerning body mass gain and food intake were analyzed by oneway analysis of variance (ANOVA) followed by Student's $t$-test, the other differences between means were tested for significance using Student's t-test. A difference betwcen the two means was considered statistically significant when $\mathrm{P}$ was $<0.05$.

The computations were performed by the use of Statgraphics Plus Version 4.1.

\section{RESULTS}

Body mass gain (g/day) did not differ significantly between groups receiving different dietary fats, both after one and three weeks of the fat-containing diet. However, significant differences appeared between body mass gain during the fat-free regimen and one and three weeks of diets containing fat (ANOVA, effect of treatment: $\mathrm{P}=0$ ) as well as between one and three weeks of feeding fat in all dietary groups (Table 2). Food intake, $\mathrm{g} / \mathrm{g}$ body weight gain, was significantly higher during the fat-free diet than during the fat-containing diet (ANOVA, $\mathrm{P}=0$ ); it did not differ among groups fed different dietary fats both during the first and the next two weeks of fat supply. Within dietary groups, food intake was not statistically different in the first and subsequent two weeks of diets containing fats, except group R where significantly lower food intake was observed during the first week $(\mathrm{P}<0.05$; Table 2$)$. Fatty acid intakes were highly differentiated between dictary groups (Table 3 ). 
TABLE 2

Body mass gains (BMG) and food intake (Fl) during feeding with fat free dict (FF) and during first weck (A) and subsequent two wecks (B) of supplying diets of different fat composition

\begin{tabular}{lccc}
\hline Group & $\mathrm{n}$ & Body mass gain, g day & Food intake, g g BMG ${ }^{\cdot 1}$ \\
\hline Fat frec diet & 8 & $29 \pm 0.5^{\mathrm{a}}$ & $5.3 \pm 1.5^{\mathrm{a}}$ \\
Diet S & 6 & $7.6 \pm 1.1^{\mathrm{b}}$ & $2.9 \pm 0.3^{\mathrm{b}}$ \\
A & 10 & $6.3 \pm 1.3^{\mathrm{b}}$ & $3.1 \pm 0.3^{\mathrm{h} . \mathrm{c}}$
\end{tabular}

Diet L

$\begin{array}{lrrl}\text { A } & 6 & 7.7 \pm 0.9^{\mathrm{b}} & 2.7 \pm 0.2^{\mathrm{h}} \\ \mathrm{B} & 10 & 5.8 \pm 0.8^{\mathrm{b}} & 3.1 \pm 0.3^{\mathrm{bcc}}\end{array}$

Diet $\mathrm{P}$

$\begin{array}{lrrr}\text { A } & 6 & 7.7 \pm 1.1^{\mathrm{b}} & 3.2 \pm 0.5^{\mathrm{b}} \\ \mathrm{B} & 10 & 5.3 \pm 0.7^{\mathrm{c}} & 3.4 \pm 0.4^{\mathrm{bcc}}\end{array}$

Diet $\mathrm{R}$
A
$7.4 \pm 0.5^{\mathrm{b}}$
$2.7 \pm 0.2^{b}$
B
$5.8 \pm 1.0^{\mathrm{c}}$
$3.2 \pm 0.3^{c}$

$\mathrm{S}$ - with sunflower oil; $\mathrm{L}$ - with lard; $\mathrm{P}$ - with palm oil; $\mathrm{R}$ - with rape seed oil

a.b.c $\mathrm{P}<0.05$

Thyroid peroxidase activity (Figure 1) was lowest after the fat-free diet regimen. After one week of fat feeding, TPO activity increased significantly in groups $\mathrm{S}(\mathrm{P}<0.0004)$ and $\mathrm{P}(\mathrm{P}<0.006)$ reaching a level significantly higher than in group $\mathrm{L}$ $(\mathrm{P}<0.0005$ and $\mathrm{P}<0.008$, respectively). In group $\mathrm{L}$, a significant increase in TPO activity $(\mathrm{P}<0.05)$ was not observed until after 3 weeks of fat consumption, while in group R, TPO activity did not change significantly during the entire period of feeding fat as compared with the fat-free regimen. After three weeks of feeding diets containing fats, TPO activity was higher in group $\mathrm{P}$ than in groups $\mathrm{L}(\mathrm{P}<0.02)$ and $\mathrm{R}(\mathrm{P}<0.003)$. Thyroid peroxidase activity was directly related to palmitic acid intake $(r=0.49 ; P<0.0001)$ and plasma total cholesterol concentration $(r=0.34$; $\mathrm{P}<0.01)$.

Corticosterone concentrations in blood plasma, adrenals and aorta decreased significantly in some groups after introducing dicts containing fat as compared with the fat-free diet period: in blood plasma in group $\mathrm{L}(\mathrm{P}<0.02), \mathrm{P}$ and $\mathrm{R}$ $(\mathrm{P}<0.04)$; in the adrenals in group $\mathrm{S}(\mathrm{P}<0.04), \mathrm{P}(\mathrm{P}<0.03)$ and $\mathrm{R}(\mathrm{P}<0.05)$, and in the aorta in group $\mathrm{R}(\mathrm{P}<0.03)$. The plasma $\mathrm{Cs}$ concentration was significantly higher in group $\mathrm{S}$ than in other groups (with group $\mathrm{P} P<0.002$; with $\mathrm{R} P<0.001$; with $\mathrm{L} P<0.0005$ ). In the adrenals it did not differ between groups; in the aorta 
TABLE 3

Fatty acid intake ( $\mathrm{mg} / \mathrm{g}$ body mass gain ${ }^{-1}$ ) during first (A) and next two weeks (B) of diet containing different dictary fats feeding after the fat free diet regimen - means and standard deviations. Intakes of each fatty acid were compared both between dietary groups and weeks of treatment within dietary group

\begin{tabular}{|c|c|c|c|c|}
\hline \multirow[t]{2}{*}{ Fatty acid } & \multicolumn{4}{|c|}{ Groups } \\
\hline & $\mathrm{S}$ & $\mathrm{L}$ & $\mathrm{P}$ & $\mathrm{R}$ \\
\hline \multicolumn{5}{|l|}{$14: 0$} \\
\hline $\mathrm{A}$ & $0.6 \pm 0.1^{a}$ & $4.6 \pm 0.3^{b}$ & $3.1 \pm 0.5^{\circ}$ & - \\
\hline B & $0.7 \pm 0.1^{\mathrm{b}}$ & $5.2 \pm 0.6^{b}$ & $3.3 \pm 0.4^{i}$ & \\
\hline \multicolumn{5}{|l|}{$16: 0$} \\
\hline A & $21.5 \pm 2.2^{\mathrm{a}}$ & $61.0 \pm 3.7^{\mathrm{h}}$ & $124.0 \pm 18.4^{\circ}$ & $11.8 \pm 0.7^{d}$ \\
\hline B & $23.3 \pm 2.3^{\mathrm{a}}$ & $69.8 \pm 7.8^{\mathrm{h}}$ & $133.6 \pm 14.1^{\circ}$ & $14.1 \pm 1.1^{\mathrm{c}}$ \\
\hline \multicolumn{5}{|l|}{ 18:0 } \\
\hline $\mathrm{A}$ & $10.8 \pm 1.1^{a}$ & $30.5 \pm 1.9^{b}$ & $13.6 \pm 2.0^{\mathrm{a}, \mathrm{c}}$ & $4.4 \pm 0.3^{\mathrm{d}}$ \\
\hline $\mathrm{B}$ & $11.6 \pm 1.2^{\circ}$ & $34.9 \pm 3.9^{\mathrm{b}}$ & $14.7 \pm 1.6^{c}$ & $5.2 \pm 0.4^{c}$ \\
\hline \multicolumn{5}{|l|}{$18: 1$} \\
\hline A & $64.4 \pm 6.6^{\mathrm{a}}$ & $149.6 \pm 9.3^{b . c}$ & $132.0 \pm 19.2^{\mathrm{h}, \mathrm{c}}$ & $133.2 \pm 8.8^{c}$ \\
\hline B & $69.3 \pm 6.9^{\mathrm{a}}$ & $171.1 \pm 19.2^{b}$ & $142.0 \pm 15.1^{b}$ & $158.9 \pm 12.3^{b}$ \\
\hline \multicolumn{5}{|l|}{$18: 2$} \\
\hline A & $162.5 \pm 16.7^{\mathrm{a}}$ & $18.3 \pm 1.1^{\mathrm{b}}$ & $34.1 \pm 5.1^{\mathrm{c}}$ & $145.7 \pm 9.5^{4}$ \\
\hline $\mathrm{B}$ & $176.5 \pm 17.4^{\mathrm{a}}$ & $20.9 \pm 2.3^{b}$ & $36.4 \pm 4.3^{\mathrm{c}}$ & $155.5 \pm 12.1^{\mathrm{a}}$ \\
\hline \multicolumn{5}{|l|}{$18: 3$} \\
\hline $\mathrm{A}$ & $9.2 \pm 0.9^{a}$ & $2.1 \pm 0.1^{\mathrm{b}}$ & $0.9 \pm 0.1^{\mathrm{c}}$ & $26.4 \pm 1.7^{\mathrm{d}}$ \\
\hline B & $10.0 \pm 1.0^{\mathrm{a}}$ & $2.4 \pm 0.3^{b}$ & $1.0 \pm 0.1^{\mathrm{c}}$ & $31.5 \div 2.4^{c}$ \\
\hline
\end{tabular}

i.,b.e. $P<0.05$

the Cs concentration was lower in group $\mathrm{R}$ than in the remaining groups $(\mathrm{P}<0.05$ in all cases) (Figure 2).

After two subsequent weeks of feeding diets with fat, a further decrease in plasma $\mathrm{Cs}$ concentration appeared in group $\mathrm{S}(\mathrm{P}<0.01)$ and an increase in group $\mathrm{L}$ $(\mathrm{P}<0.002)$, as compared with values observed after one week of feeding fat, reaching levels that were not statistically different among groups and significantly lower than after the fat-free period (in all groups $\mathrm{P}<0.001$ ). In the adrenals, the Cs concentration increased in groups $\mathrm{P}$ and $\mathrm{R}(\mathrm{P}<0.01$ and $\mathrm{P}<0.02$, respectively) and was lower in group $S$ than in groups $P$ and $R(P<0.01$ in both cases $)$. Only in group $\mathrm{S}$ did the $\mathrm{Cs}$ concentration in the adrenals remain significantly lower than after the fat-free regimen $(\mathrm{P}<0.001)$. In the aorta in groups $\mathrm{S}$ and $\mathrm{L}$, the $\mathrm{B}$ level became 


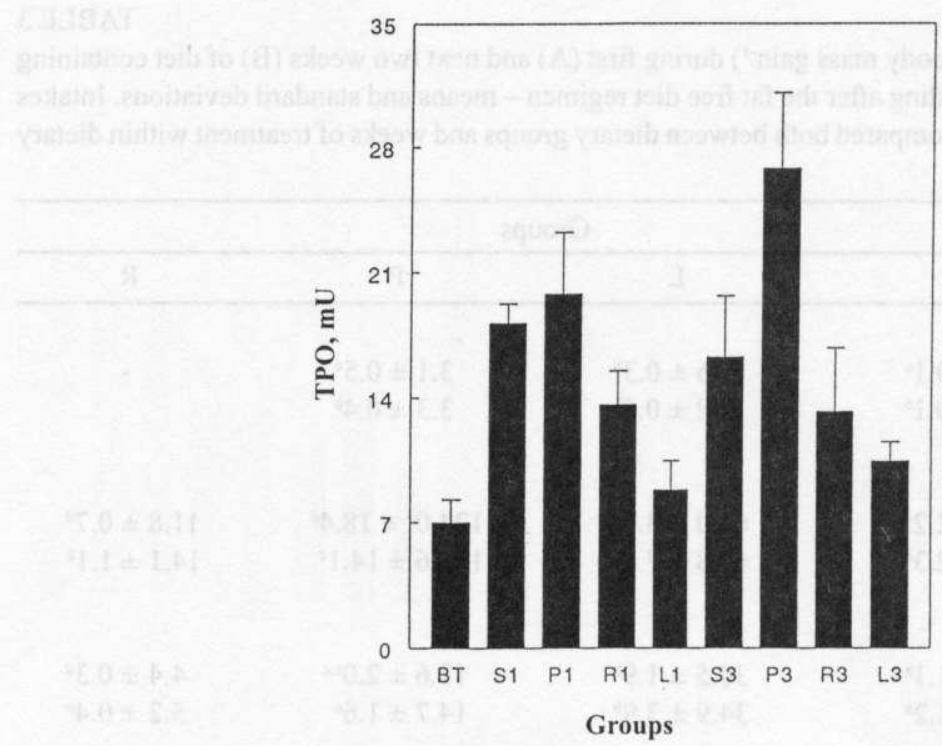

Figure 1. Thyroid peroxidase activity in thyroid microsomal fraction of rats after 1 week of fat-free regimen (BT) and after feeding diets with different fats during subsequent one week (sunflower oil fed -S1; palm oil - P1; rape seed oil - R1 and lard - L1) and three weeks (sunflower oil fed - S3; palm oil - P3; rape seed oil - R3; lard - L3). For statistical significance see text. Values are expressed as means with SE

significantly lower than after the fat-free regimen (in group $\mathrm{S} \mathrm{P}<0.05$; in group $\mathrm{L}$ $\mathrm{P}<0.01)$. An elevation in the Cs concentration, as compared with the one-week period of feeding fat appeared in group $\mathrm{R}(\mathrm{P}<0.05)$ and the $\mathrm{Cs}$ concentration became higher in group $\mathrm{R}$ than in $\mathrm{L}(\mathrm{P}<0.01$, Figure 2$)$.

The cardiac Cs concentration was lowest after the fat-free diet regimen. After one week of feeding diets containing fat, the concentration of this hormone increased significantly in groups $\mathrm{S}(\mathrm{P}<0.03)$ and $\mathrm{R}(\mathrm{P}<0.05)$ as compared with values observed after the fat-free regimen and was lower in group $\mathrm{P}$ than in group $\mathrm{S}$ $(\mathrm{P}<0.01)$ and $\mathrm{R}(\mathrm{P}<0.001)$. A significant increase in cardiac Cs concentration, as compared with the fat-free diet period occurred in groups $\mathrm{L}$ and $\mathrm{P}$ after three weeks of fat supply ( $\mathrm{P}<0.001$ and 0.01 , respectively). After three weeks of feeding fat, the Cs concentration was higher than after one week in groups $\mathrm{S}(\mathrm{P}<0.003), \mathrm{L}$ $(\mathrm{P}<0.02)$ and $\mathrm{P}(\mathrm{P}<0.007)$ and lower in groups $\mathrm{P}$ and $\mathrm{R}$ than in group $\mathrm{S}(\mathrm{P}<0.05$ and $\mathrm{P}<0.01$, respectively) and $\mathrm{L}(\mathrm{P}<0.05$ in both cases) (Figure 2$)$. Adrenal $\mathrm{Cs}$ concentration was directly related to total fat consumption $(\mathrm{r}=0.37 ; \mathrm{P}<0.006)$ and oleic acid intake $(\mathrm{r}=0.39 ; \mathrm{P}<0.04)$; cardiac $\mathrm{Cs}$ concentration was positively correlated with total fat consumption $(\mathrm{r}=0.59 ; \mathrm{P}<0.0001)$ and negatively with palmitic 


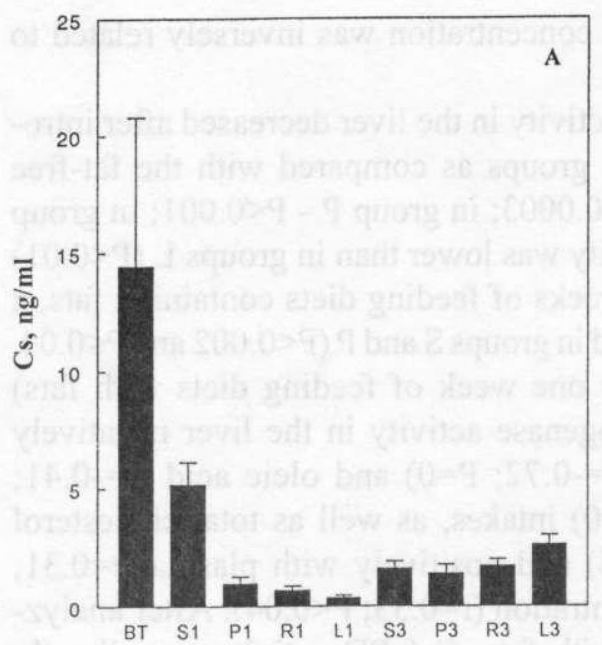

Groups

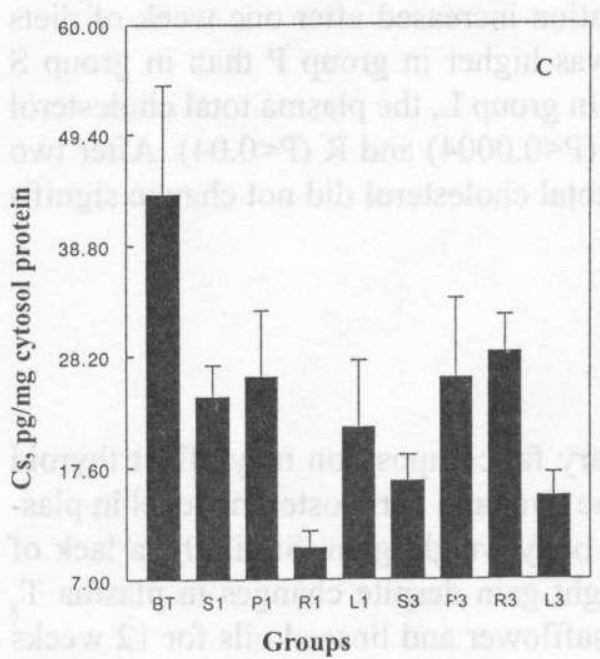

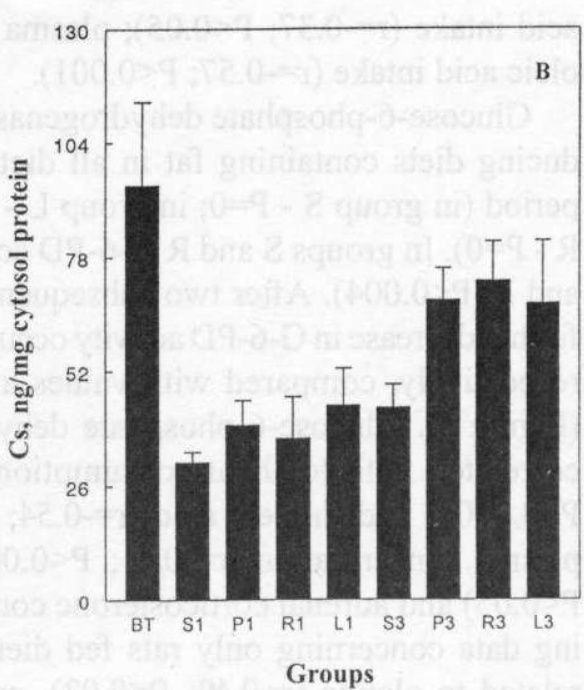

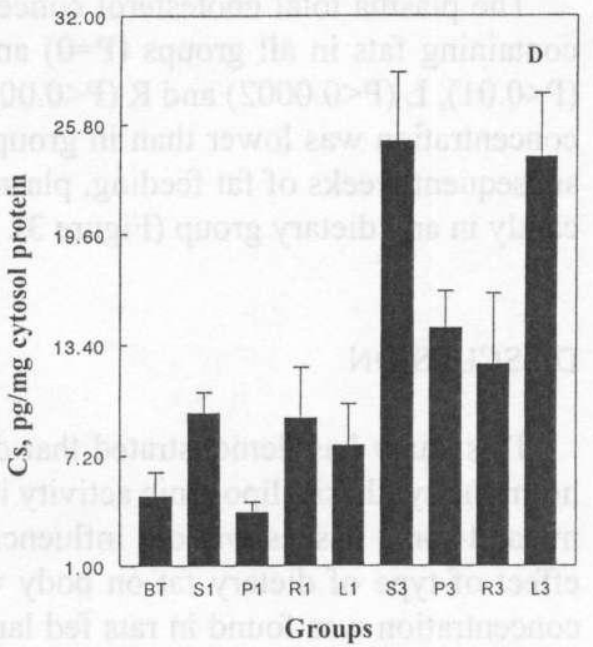

Figure 2. Corticosterone concentrations in blood plasma (A) and cytosol fractions of adrenals (B), aorta (C) and heart (D) in rats after 1 week of fat-free diet feeding and after one and three weeks of diets with different fat supply. Explanations as for the Figure 1 
acid intake $(\mathrm{r}=-0.37 ; \mathrm{P}<0.05)$; plasma $\mathrm{Cs}$ concentration was inversely related to oleic acid intake $(\mathrm{r}=-0.57 ; \mathrm{P}<0.001)$.

Glucose-6-phosphate dehydrogenase activity in the liver decreased after introducing diets containing fat in all dietary groups as compared with the fat-free period (in group $\mathrm{S}-\mathrm{P}=0$; in group $\mathrm{L}-\mathrm{P}<0.0003$; in group $\mathrm{P}-\mathrm{P}<0.001$; in group $R-P=0)$. In groups $S$ and $R G-6-P D$ activity was lower than in groups $L(P<0.01)$ and $P(P<0.004)$. After two subsequent weeks of feeding diets containing fats, a further decrease in G-6-PD activity occurred in groups $\mathrm{S}$ and $\mathrm{P}(\mathrm{P}<0.002$ and $\mathrm{P}<0.04$, respectively, compared with values after one week of feeding dicts with fats) (Figure 3). Glucose-6-phosphate dehydrogenase activity in the liver negatively correlated with total fat consumption $(\mathrm{r}=-0.72 ; \mathrm{P}=0)$ and oleic acid $(\mathrm{r}=-0.41$; $\mathrm{P}<0.0004)$ and linoleic acid $(\mathrm{r}=-0.54 ; \mathrm{P}=0)$ intakes, as well as total cholesterol plasma concentration $(\mathrm{r}=-0.41 ; \mathrm{P}<0.0005)$ and positively with plasma $(\mathrm{r}=0.31$; $\mathrm{P}<0.05)$ and adrenal corticosterone concentration $(\mathrm{r}=0.33 ; \mathrm{P}<0.04)$. After analyzing data concerning only rats fed diets with fats, G-6-PD activity was directly related to oleinic $(\mathrm{r}=0.49 ; \mathrm{P}<0.03)$, palmitic $(\mathrm{r}=0.81 ; \mathrm{P}=0)$ and stearic $(\mathrm{r}=0.49$; $\mathrm{P}<0.03)$ acid intakes, inversely with linoleic $(\mathrm{r}=-0.66 ; \mathrm{P}<0.0002)$ and linolenic $(\mathrm{r}=-0.61 ; \mathrm{P}<0.005)$ acid intakes.

The plasma total cholestcrol concentration increased after one week of diets containing fats in all groups $(\mathrm{P}=0)$ and was higher in group $\mathrm{P}$ than in group $\mathrm{S}$ $(\mathrm{P}<0.01), \mathrm{L}(\mathrm{P}<0.0002)$ and $\mathrm{R}(\mathrm{P}<0.008)$. In group $\mathrm{L}$, the plasma total cholesterol concentration was lower than in group $\mathrm{S}(\mathrm{P}<0.0004)$ and $\mathrm{R}(\mathrm{P}<0.04)$. After two subsequent weeks of fat feeding, plasma total cholesterol did not change significantly in any dietary group (Figure 3 ).

\section{DISSCUSSION}

This study has demonstrated that dietary fat composition may affect thyroid hormone synthesis, lipogenic activity in the liver and corticosterone level in plasma and some tissues without influencing body weight gain. Similarly, a lack of effect of type of dietary fat on body weight gain despite changes in plasma $\mathrm{T}_{3}$ concentration was found in rats fed lard, safflower and linseed oils for 12 weeks (Takeuchi et al., 1995), however, in another experiment where the $\mathrm{T}_{4}$ plasma level was differentiated by dietary fat composition, a lower body weight was found in rats fed beef tallow than in rats fed prime rib and safflower oil for a period of 5 weeks (Smith et al., 1993) although a relationship between body weight gain and $\mathrm{T}_{4}$ plasma concentration was not found.

To our knowledge, this is the first time that thyroid peroxidase activity has been shown depend on type of dietary fat. The lower TPO activity in rats fed lard is consistent with the lower plasma thyroid hormone level found by others in rats fed 

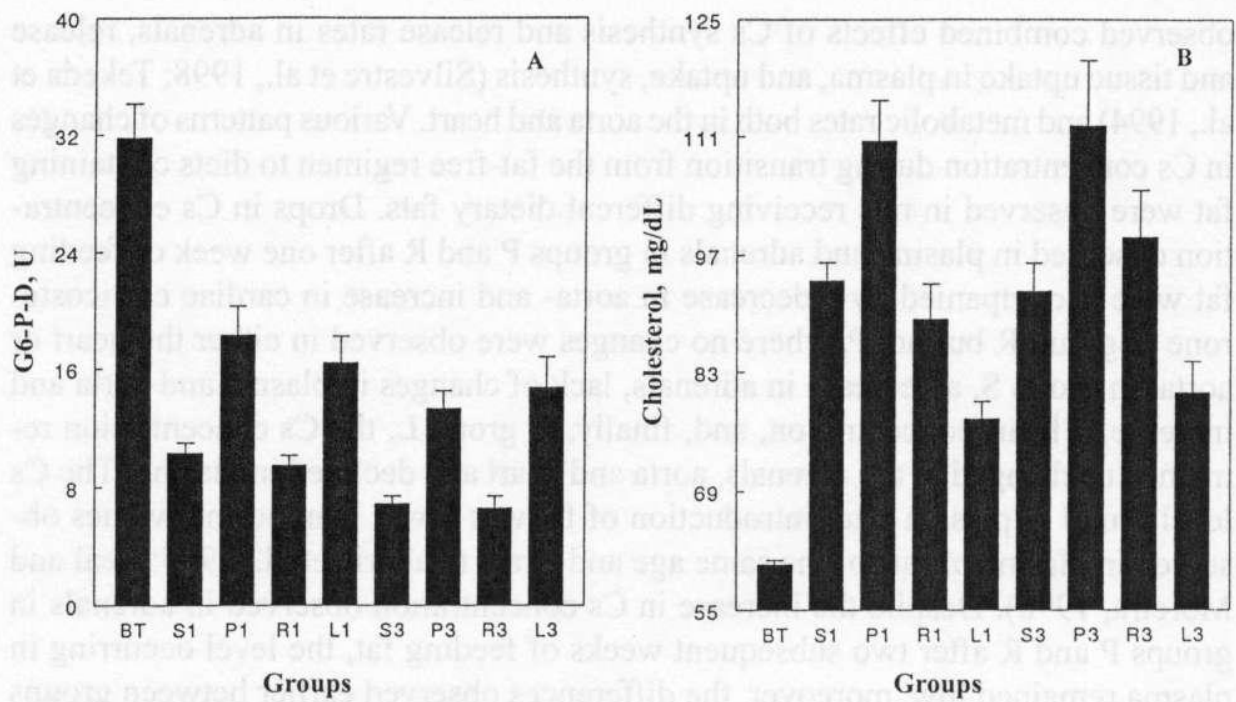

Figure 3. Glucose-6-phosphate dehydrogenase activity in liver cytosolic fraction (A) and plasma total cholesterol concentration (B) in rats after period of fat-free diet feeding and after one and three weeks of diets with different fat supply. Explanations as for the Figure 1

this fat as compared with safflower oil (Smith et al., 1993) and linseed oil (Tekeuchi et al., 1995). This could suggest a stimulating effect of polyunsaturated fatty acids on thyroid gland activity. TPO activity was, however, directly related to palmitic acid intake and plasma cholesterol concentration and reached the highest value in rats receiving the diet with palm oil, known to be rich in saturated fatty acids. Moreover, palm oil has been shown to contain a high level of carotenoids that are precursors of retinoic acid found to inhibit TPO gene expression (Arai et al., 1991; Namba et al., 1993). Therefore, it could be supposed that lower membrane fluidity connected with more saturated fat consumption promotes higher activity of membrane-bound TPO. The high plasma cholesterol concentration in rats fed palm oil could be related to its higher content in membrane phospholipids, which was shown to increase cellular uptake of thyroid hormone (Chehin et al., 1995). Higher uptake of thyroid hormones could decrease their level in the circulation and have an inhibitory influence on TRH and TSH secretion leading to greater stimulation of thyroid activity. Taking into consideration stimulation of cholesterol receptor synthesis by thyroid hormone, such effects could be treated as a regulatory loop protecting against undesirable increases in plasma cholesterol levels.

Corticosterone concentrations in plasma and tissues studied were affected by experimental conditions in different ways, suggesting their influence on alterations in hormone distribution. It should be mentioned that in our experiment, we 
observed combined effects of Cs synthesis and release rates in adrenals, release and tissue uptake in plasma, and uptake, synthesis (Silvestre et al., 1998; Tckeda et al., 1994) and metabolic rates both in the aorta and heart. Various patterns of changes in Cs concentration during transition from the fat-free regimen to diets containing fat were observed in rats receiving different dietary fats. Drops in Cs concentration observed in plasma and adrenals in groups $\mathrm{P}$ and $\mathrm{R}$ after one week of feeding fat were accompanicd by a decrease in aorta- and increase in cardiac corticosterone in group $\mathrm{R}$ but not $\mathrm{P}$, where no changes were observed in either the heart or aorta. In group $\mathrm{S}$, a decrease in adrenals, lack of changes in plasma and aorta and increase in heart concentration, and, finally, in group L, the Cs concentration remained unchanged in the adrenals, aorta and heart and declined in plasma. The Cs level found in plasma after introduction of fat was lower than normal values observed in plasma of rats of the same age and strain (Laborie et al., 1995; Leal and Moreira, 1996). Despite the increase in Cs concentration observed in adrenals in groups $P$ and $R$ after two subsequent weeks of feeding fat, the level occurring in plasma remained low, moreover, the differences observed carlier between groups disappeared. This suggests high tissue uptake of $\mathrm{Cs}$ after a period of fat deprivation. After three weeks of fat supply, the effect of dietary fat composition on Cs concentration in tissues persisted. Surprisingly, eating rape seed and palm oil seemed to promote lower $\mathrm{Cs}$ concentrations in the heart than consumption of sunflower and lard. However, the opposite took place in the aorta. These results are difficult to explain with respect to different fatty acid compositions of these pairs of fats; the only similarity between palm and rape seed oils exists in the oleic acid level. It should be mentioned that dietary oleic acid was found to increase the glucocorticoid-producing rate in cultured rat adrenocortical cells (Sarel and Widmaier, 1995).

The lack of changes or decrease in Cs concentration observed in plasma and all tissues except the heart after introducing diets containing fats are rather surprising taking into account data indicating an increase in adrenal cortex activity accompanying a rise in dietary fat content from 4 to $20 \%$ of diet (w/w) (Tannenbaum et al., 1997) and from 12.3 to $54 \%$ cal from fat independent of the kind of fat (Kamara et al., 1998), or in response to Intralipid infusion (Widmaier et al., 1992). However, other studies show lower plasma Cs concentrations in rats fed a diet with $30 \%$ fat than containing $10 \%$ fat $(\mathrm{w} / \mathrm{w})$ but no differences between rats consuming diets with 30 and $60 \%$ fat (Leibowitz et al., 1998) or lower plasma Cs concentration in rats receiving 40 than $7 \%(\mathrm{w} / \mathrm{w})$ fat in diets (Boivin and Deshaies, 1995). It should be noted that after three weeks of fat supply, the Cs concentration in adrenals reached a level that was not significantly different from that observed on a fat-free regimen in all groups except the one fed sunflower oil.

As expected, the highest G-6-PD activity was noted on the fat-free diet and its drop after the introduction of fat-containing diets depended on dietary fat composition. The decrease in G-6-PD activity was more profound in rats consuming sun- 
flower and rape seed oils; this was directly related to monounsaturated and saturated acid intake and inversely to polyunsaturated acid intake according to data showing the inhibition of G-6-PD synthesis by polyunsaturated fatty acids (Clarke et al., 1976). Surprisingly, comparison of TPO and G-6-PD activity clearly indicates that these enzymes are differently influenced by dietary fat, although triiodothyronine has been shown to stimulate G-6-PD activity (Roncari and Murthy, 1975; Miksicek and Towle, 1982). Contrary to this, the stimulatory effect of glucocorticoids on G-6-PD activity (Berdanier, 1989) could be reflected by direct relation of G-6-PD activity and level of Cs in plasma and the adrenals, but not in the heart and aorta, found in our work. However, while both G-6-PD activity and plasma $\mathrm{Cs}$ concentration were higher after the fat-free regimen than during feeding diets containing fat, plasma Cs concentrations, in contrast with G-6-PD activity, were independent of dietary fat composition.

In our experiment, the plasma cholesterol concentration was highest in rats receiving the palm oil diet and, surprisingly, lower in rats fed the diet with lard than sunflower and rape seed oil diets. It could be supposed that the effect of feeding palm oil on plasma cholesterol could be due to the high level of palmitic acid known to increase plasma cholesterol (Ghadack et al., 1992). The low level of cholesterol in rats receiving lard may be the result of body cholesterol homeostasis regulation leading to plasma cholesterol being not higher than in rats fed vegetable, cholesterol-free, oils (Jacobson et al., 1974).

In conclusion, it can be stated that by differently affecting the thyroid, adrenal glands and hepatic lipogenic activity, dictary fat composition may change the relations among them.

\section{REFERENCES}

Abrams J.J., Grundy S.M., 1981. Cholesterol metabolism in hypothyroidism and hyperthyroidism in man. J. Lipid Res. 22, 323-338

Arai M., Tsushima T., Isozaki O., Shizume K., Emoto N., Demura H., Miyakawa M., Onoda N., 1991. Effects of retinoids on iodine metabolism, thyroid peroxidase gene expression and dcorybonucleic acid synthesis in porcine thyroid cells in culture. Endocrinology 129, 2827 2833

Ariff̌n A., Basri M.N.H., Ahmad M.J., Othman R., 1994. Selected readings on palm oil and its uses. Palm Oil Research Institute of Mataysia, p.162

Berdanier C.D., 1989. Role of the glucocorticoids in the regulation of lipogenesis. FASEB J. 3 , 2179-2183

Bianco A.C., Sheng X., Silva J.E., 1988. Triiodothyronine amplifies norepinephrine stimulation of uncoupling protein gene transcription by a mechanism not requiring protein synthesis $\mathrm{J}$. Biol. Chem. 263, 18168-18175 
Boivin A., Deshaies Y., 1995. Dietary rat models in which the development of hypertriglyceridemia and that of insulin resistance are dissociated. Metabolism 44, 1540-1547

Bray G.A., Fisler J., York D.A., 1990. Neuroendocrine control of the development of obesity: understanding gained from studies of experimental animal models. Front. Neuroendocrinol. 11, 128181

Chehin R.N., Rintoul M.R., Morero R.D., Farias R.N., 1995. Differential effects of triiodothyronine and thyroxine on liposomes containing cholesterol: physiological speculations. J. Membrane Biol. 147, 217-221

Clarke S.D., Ronsos D.R., Leveille G.A., 1976. Specific inhibition of hepatic fatty acid synthesis extracted by dietary linoleate and linolenate in essential fatty acid adequate rats. Lipids I I, 485490

Dallman M.F., Strack A.M., Akana S.F., Bradbury M.J., Hanson E.S., Scribner K.A., Smith M., 1993. Feast and famine: critical role of glucocorticoids with insulin in daily energy flow. Front. Neuroendocrino!. 14, 303-347

Freake H.C., Schwartz II.L., Oppenheimer J.H., 1989. The regulation of lipogenesis by thyroid hormone and its contribution to thermogenesis. Endocrinology 125. 2868-2874

Garrel D.R., 1997. Glucocorticoids and energy expediture: relevance to the regulation of energy balance in man. Nutrition 13,482-483

Ghatak A., Monte G., Garcia M., 1992. Review: Effects of dietary fatty acids and fibers on blood cholesterol. Jpn. J. Med. Sci. Biol. 45, 99-111

Hodgson J.M., Wahlqvist M.L., Boxall J.A.. 1993. Can linoleic acid contribute to coronary artery disease? Amer. J. Clin. Nutr. 58, 228-234

Hosoya T., Sato I., Hiyama Y., Yoshimura H., Niimi H., Tarutani O., 1985. An improved assay method for thyroid peroxidase applicable for a few milligrams of abnormal human thyroid tissues. J. Biochem. 98, 637-647

Jacobson N.L., Richard M., Berger P.J., Kluge J.P., 1974. Comparative effects of tallow, lard and soybean oil, with and without supplemental cholesterol, on growth, tissue cholesterol and other responses of calves. J. Nutr. 104, 573-579

Kamara K., Eskay R., Castonguay T., 1998. High-fat diets and stress responsivity. Physiol. Behav. $64,1-6$

Laborie C., Bernet F., Kerckacrt J.P., Maubert E., Lesage J., Dupouy J.P., 1995. Regulation of neuropeptide $\mathrm{Y}$ and its mRNA by glucocorticoids in the rat adrenal gland. Neuroendocrinology $62,601-610$

Leal A.M.O., Morcira A.C., 1996. Feeding and the diurnal variation of the hypothalamic-pituitaryadrenal axis and its responses to CRH and ACTH in rats. Neuroendocrinology 64, 14-19

Lee C.J., 1982. Glucose 6-phosphate dchydrogenase from mouse. Methods Enzymol. 89, 252-260

Lcibowitz. S.F., Akabayashi A., Wang J., 1998. Obesity on a high-fat dict: role of hypothalamic galanin in neurons of the anterior paraventricular nucleus projecting to the median eminence. J. Neurosci. 18, 2709-2719

Lim Ch., Munro S.L.A., Wynne K.N., Topliss D.J., Stockigl J.R., 1995. Influence of nonesterified fatty acids and lysolecithins on thyroxine binding to thyroxine - binding globulin and transthyretin. Thyroid 5, 319-324

Lin M.H., 1979. $\mathrm{Na}^{+}, \mathrm{K}^{+}$-ATPase enzyme units in lean and obese (ob/ob) thyroxine -injected mice. Amer, J. Physiol. 237, E265-E272

Lowry O.H., Rosebrough N.J., Favy A.L., Randall O.P., 1951. Protein measurment with Follin phenol reagent. J. Biol. Chem. 193, 265-275

Los-Kuczera M., Pickarska J., 1988. Composition and Nutritive Value of Food (in Polish). PZWL, Warszawa, pp. 325 
Mangold H.K., Bezzegh T., 1974. Routine methods of lipid analysis. In: H.Ch. Curtius, M. Roth (Editors). Clinical Biochemistry. Principles and Methods. Walter de Gruyter, Berlin, pp. 10361037

Miksicek R.J., Towle H.C., 1982. Changes in the rates of synthesis and messenger RNA levels of hepatic glucose-6-phosphate and 6-phosphogluconate dehydrogenases following induction by diet or thyroid hormone. J. Biol. Chem. 257, 11829-11835

Namba H., Yamashita S., Morita S., Villadolid M.C., Kimura H., Yokoyama N., Izumi M., Ishikawa N., Ito K., Nagataki S., 1993. Retinoic acid inhibits human thyroid peroxidase and thyroglobulin gene expression in cultured human thyrocytes. J. Endocrinol. Invest. 16, 87-93

Ness G.C.. Lopez D., 1995. Transcriptional regulation of rat hepatic low-density lipoprotein receptor and cholesterol 7 ahydroxylase by thyroid homone. Arch. Biochem. Bioplyys. 323, 404-408

Nunez J., 1980. lodination and thyroid hormone synthesis. In: M. de Visscher (Editor). Thyroid Gland. Raven Press, New York, pp. 39-59

Roncari D.A.K., Murthy V.K., 1975. Effect of thyroid hormones on enzymes involved in fatty acid and glicerolipid synthesis. Evidence for tissues specifity. J. Biol. Chem. 250, 4134-4138

Rosolowska-Huszcz. D., 1998. Effect of exercise training intensity on thyroid activity at rest. J. Physiol. Pharmacol. 49, 457-466

Sarel I.,, Widmaier E.P., 1995. Stimulation of steroidogenesis in cultured rat adrenocortical cells by unsaturated fatty acids. Amer. J. Physiol. 268, R1484-R1490

Silvestre J.S., Robert V., Heymes C., Aupetit-Faisant B., Mouas C., Moalic J.M., Swynghedauw B., Delcayre C., 1998. Myocardial production of aldosterone and corticosterone in the rat. Physiological regulation. J. Biol. Chem. 273, 4883-4891

Smith S.M., Johnson P.E., Lukaski H.C., 1993. In vitro hepatic thyroid hormone deiodination in iron-deficient rats: effect of dietary fat. Life Sci. 53, 603-609

Stupnicki R., 1985. Glicorticosteroids. In: F. Kokot, R. Stupnicki (Editors). Radioimmunossay and Radiocompetition Methods Applied in Clinics (in Polish). PZWL, Warszawa, pp. 235-244

Takeda Y., Miyamori I., Yoneda T., lki K., Hatckeyama H., Blair I.A., Hsien F.Y., Takeda R., 1994. Synthesis of corticosterone in vascular wall. Endocrinology 135, 2283-2286

Takeuchi H., Matsuo T., Tokuyama K., Suzuki M., 1995. Serum triiodothyronine concentration and $\mathrm{Na}, \mathrm{K}$-ATPase activity in liver and skeletal muscle are influenced by dictary fat type in rats. J. Nutr. $125,2364-2369$

Tannenbaum B.M., Brindley D.N., Tannenbaum G.S., Dallman M.F., McArthur M.D., Meancy M.J., 1997. High-fat feeding alters both basal and stress-induced hypothalamic-pituitary-adrena! activity in the rat. Amer. J. Physiol. 36, E1168-E1177

van der Klis F.R.M., Schmid E.D.L., van Beeren H.C., Wiersinga V.M., 1991. Competitive inhibjtion of $\mathrm{T}_{3}$ binding to $\mathrm{a}_{1}$ and $\mathrm{b}_{1}$ thyroid hormone receptors by fatty acids. Biochem Biophys. Res. Commun. 179, 1011-1016

Widmaier E.P., Rosen K., Abbott B., 1992. Free fatty acids activate the hypothalamic-pituitaryadrenocortical axis in rats. Endocrinology 131, 2313-2318 


\section{STRESZCZENIE}

\section{W plyw składu tłuszczowego diety na aktywność peroksydazy tarczycowej, 6-fosfo-gluko-dehy- drogenazy wątrobowej i stężenia kortykosteronu w osoczu i tkankach szczurów}

U szczurów żywionych dietami zawierającymi różne rodzaje thuszczu badano aktywność tarczycy i kory nadnerczy oraz aktywność lipogeniczną wątroby.

Szczury samce rasy Wistar o ciężarze ciała 100-120 g, po tygodniowej diecie beztłuszczowej (BT), podzielono na 4 grupy, z których każda otrzymywała diety zawierające inny rodzaj tłuszczu: grupa $L-z e$ smalcem, $S-z$ olejem słonecznikowym, $P-z$ olejem palmowym i $R-z$ olcjem rzepakowym. Udział tłuszczu we wszystkich grupach był taki sam i wynosił wagowo $10 \%$. Po tygodniu karmienia dietą beztłuszczową oraz po 1 i 3 tygodniach żywienia dietami zawierającymi tłuszcz oznaczano aktywność tarczycowej peroksydazy jodującej (TPO), stężenie kortykosteronu (Cs) w osoczu oraz, we frakcji cytosolowcj nadnerczy, ściany aorty i serca, stężenie całkowitego cholesterolu w osoczu i aktywność dehydrogenazy glukozo-6-fosforanu (G-6-PD), bçdącej miarą aktywności lipogenicznej wątroby.

Aktywność TPO wzrosła po ! tygodniu stosowania diet zawierajacych tłuszcz w grupach S i P, po 3 tygodniach była wyższa w grupach P, S i L niż na diccie BT. Była ona równicż dodatnio skorelowana ze spożyciem kwasu palmitynowego oraz stężeniem całkowitego cholesterolu w osoczu. Stężenie Cs w osoczu, w porównaniu z dietą BT, po 3 tygodniach żywienia dietami thuszczowymi, było niższe niczalcżnie od ich rodzaju, natomiast w cytosolach tkanek było wyższe niż na diecie BT i zależało od rodzaju podawanego tłuszczu: w nadnerczach w grupie $P$ i $R$, w aorcie w grupie $R$, a w sercu w grupie L i S. Niższe w stosunku do diety BT stężenic Cs stwierdzono $\mathrm{w}$ grupic $\mathrm{S}$ (aorta $\mathrm{i}$ nadnercza) oraz w grupic L (serce). Aktywność G-6-PD w wątrobie zmalała po wprowadzeniu diet zawierających tłuszcz zależnie od rodzaju thuszczu i była niższa w grupie $\mathrm{S}$ i $\mathrm{R}$ w porównaniu z grupa L i P. 